\title{
A Strategic Analysis of Improving the Ideological and Political Education Ability of Counselors in Higher Vocational Colleges from the Perspective of Fostering Virtue Through Education
}

\author{
Rui Qiao*, Yeni Hao \\ Shaanxi Artistic Vocational College, Xi' an 710000, Shaanxi, China. \\ E-mail: 259345822@qq.com
}

\begin{abstract}
Counselors are the backbone of university education and teaching activities. In the teaching activities with the fundamental task of cultivating people, the counselors of higher vocational colleges are responsible for the ideological and political education training activities of students in higher vocational colleges. However, with the changes in the educational activities of higher vocational colleges, students are faced with a diversified cultural atmosphere, which makes the current ideological and political education ability of the instructors of higher vocational colleges unable to meet the current training needs. In this regard, it is necessary to effectively improve the ideological and political education ability of counselors in higher vocational colleges. Therefore, the following article analyzes the status quo of the ideological and political education ability of counselors in higher vocational colleges under the background of fostering virtue through education, and explores the improvement strategies of the ideological and political education ability of college counselors. It aims to provide more powerful support to the educational activities of higher vocational colleges.

Keywords: Fostering Virtue Through Education; Higher Vocational Colleges; Instructors; Ideological and Political Education Ability

The report of the 19th National Congress of the Communist Party of China clearly requires education to implement the fundamental task of establishing morality and fostering people. As an important training base for vocational and technical talents, vocational colleges must implement the fundamental task of fostering virtue through education to cultivate people, so that they can train high-quality socialist builders. At the same time, in the important period of the expansion of higher vocational colleges, the student groups faced by counselors are more complicated. At present, the counselors of higher vocational colleges should accurately grasp the scientific connotation of fostering virtue through education, continuously strengthen their quality and capabilities, and create a new situation of moral education in higher vocational colleges.
\end{abstract}

\section{The status quo of ideological and political education for counselors in higher vocational colleges from the perspective of fostering virtue through education}

\subsection{Insufficiency of counselors in higher vocational colleges from the perspective of fostering virtue through education}

With the urgent needs of social professional talents, the further expansion of vocational colleges has brought new challenges to the ideological and political education work of vocational college counselors. It is reflected in that the current ideological and political education team of counselors in higher vocational colleges is insufficient, which cannot meet the development needs of higher vocational colleges under expanded enrollment. For example, in the previous vocational college counselor management workers, there were only more than 40 students in a class. The expansion of enrollment led to an increase in the number of student groups faced by counselors, and students also showed a trend of personalized development. This poses new challenges to the ideological and political education of counselors in higher vocational colleges. On the other hand, under the background of fostering virtue through education, as the main body of educational activities

Copyright (C) 2020 Rui Qiao et al

doi: $10.18282 /$ le.v9i6.1322

This is an open-access article distributed under the terms of the Creative Commons Attribution Non-Commercial License

(http://creativecommons.org/licenses/by-nc/4.0/), which permits unrestricted non-commercial use, distribution, and reproduction in any medium, provided the original work is properly cited. 
and student management activities, vocational college counselors need to integrate the ideological and political education content in the new era into every link of student management. However, there is a relatively backward team of counselors, and most counselors are not clear about the party's new education policy and the latest social ideological and political trends, which leads to the low quality and efficiency of the ideological and political education activities carried out.

\subsection{Higher vocational colleges do not pay much attention to the ideological and political education of counselors from the perspective of fostering virtue through education}

In the current higher vocational colleges, there is a phenomenon of excessive pursuit of scale and ignoring the quality of education. Ideological and political education, as an important link in teaching activities, has not been continuously updated and developed with the changes of the times. In the ideological and political education activities of higher vocational colleges, there are still situations of one-sided cognition and random teaching practice. On the one hand, higher vocational colleges do not pay much attention to the ideological and political education of counselors, and overemphasize that the work of counselors needs to be employment-oriented rather than the task of moral education. Therefore, the daily education and management activities of counselors are mainly based on how to improve students' professional skills and vocational abilities, and ideological and political education activities cannot be systematically taught and developed. On the other hand, even if most vocational colleges organize counselors to carry out ideological and political education activities, their teaching content is backward. Especially with the development of the fundamental task of fostering virtue through education, the role of counselors and professional ideological and political teachers in the students' ideological and political education is different. However, counselors have not been able to clearly recognize the problem. It only regards morality as a teacher's morality, separates the two modules of morality and cultivating people rigidly, attaches importance to moral education but neglects the whole process of education.

\section{The significance of improving the ideological and political education ability of vocational college counselors from the perspective of fostering virtue through education}

Based on the above analysis, it can be seen that under the guidance of the fundamental educational mission of Fostering Virtue Through Education, the ideological and political education ability of the instructors of higher vocational colleges clearly shows basic conditions such as insufficient investment and insufficient stamina. This urgently requires higher vocational colleges to pay attention to the improvement and cultivation of counselors' ideological and political education ability. Only in this way can colleges effectively implement the important measures of the party's education policy in the new era, promote the all-round and comprehensive development of students in vocational colleges, and support vocational colleges to take the path of sustainable development and truly contribute to providing high-quality and high-level talents to social and economic development.

\section{Effective strategies to improve the ideological and political education ability of vocational college counselors from the perspective of Fostering Virtue Through Education}

\subsection{Attach importance to the ideological and political education of counselors, create a good teaching environment for ideological and political education}

Improving the ideological and political education ability of the instructors of higher vocational colleges requires that higher vocational colleges fundamentally attach importance to ideological and political education activities, and grasp the scientific connotation and innovative changes of ideological and political education, so that they can provide necessary tools, places, activities, etc. of ideological and political education work to counselors. At present, higher vocational colleges are required to regard ideological and political education activities as the foundation of running schools, and put fostering virtue through education in the same important position as vocational skills training activities, so as to formulate a series of teaching plans, teaching goals and tasks. In addition, higher vocational colleges should carry out high-quality ideological and political education activities to better guide counselors to help them correctly recognize the difference between the functional role of counselors in ideological and political education and professional ideological and political teachers. For example, theoretical education can be carried out by professional ideological and political courses, and the instructor implements ideological and political education in students' practical activities, and develops other forms and other content of ideological and political education by using class meetings, psychological counseling classes, and second classrooms, thus gradually introducing high-quality ideological and political education activities. 


\subsection{Improve the construction and management of the counselor team, and enhance the quality and ability of counselors through multiple channels}

In view of the current insufficient number of counselors in higher vocational colleges, a younger team structure, and insufficient professional knowledge, higher vocational colleges are required to adopt a variety of methods, from the management training of counselors to the reconstruction of the counselor team through incentive activities. First, higher vocational colleges are required to constantly add new recruits and provide counselors in accordance with relevant regulations to ensure the stability of the counselor team. For example, by recruiting counselors with a similar proportion of men and women, the ideological and political education capabilities of counselors can be complemented and developed. By improving the management mechanism of the instructor team, senior students can assist the instructors to carry out ideological and political education work, to achieve a combination of theory and practice, and continuously improve the capability of the instructor team. Second, higher vocational colleges are required to develop a variety of education and training activities to strengthen and improve the professional capabilities of counselors. Ideological and political education activities for counselors in higher vocational colleges require pre-job training and regular business training. This requires higher vocational colleges to pay attention to the proportion of the pre-job training of ideological and political education for counselors to ensure that counselors can have high teaching ethics. be able to master the latest ideological and political education content, have practical application and innovation capabilities, and can continuously discover and solve problems in students' ideological and political education activities.

\subsection{Pay attention to the concept of the whole process of education and use "Internet +" to innovate education and teaching methods}

As the leader of ideological and political education activities, counselors in higher vocational colleges, their own professional skills and ideological and political abilities also directly affect the quality and efficiency of the educational work they carry out. Therefore, colleges must start from the root and strengthen the counselor's own theoretical cultivation. The counselor must be a firm believer, supporter and practitioner of Marxism, who is able to actively participate in various party organization activities organized by the school and apply Xi Jinping's new thoughts on socialism with Chinese characteristics in the new era, to insist on the unity of teaching and educating people. In this regard, in the information age, counselors can take advantage of the development trend of "Internet +". On the one hand, they can learn and improve their ideological and political literacy from the Internet to ensure that their educational activities can keep pace with the times. On the other hand, counselors are required to use the Internet+ to carry out educational activities, and continuously improve the quality and efficiency of their ideological and political education through innovative educational concepts and new technologies.

\section{Conclusion}

To sum up, the instructors of higher vocational colleges must fulfill the fundamental task of educating people by virtue and cultivation. In the increasingly chaotic social environment, the counselors of higher vocational colleges are facing more and more new problems. For example, the current counselors of the moral education of higher vocational colleges must be able to continuously adjust their work and change the tradition. The ideological and political education of counselors in higher vocational colleges has problems such as unclear connotations, unclear direction, and weak ability. At present, we can effectively achieve the fundamental task of cultivating people in higher vocational colleges by creating a team of counselors with high ideological and political education quality, creating a good ideological and political education environment, and providing rich ideological and political education resources. For example, based on the insufficient number of counselors in higher vocational colleges, it is possible to improve the salary of counselors in higher vocational colleges to attract talents with higher educational and innovative capabilities. For higher vocational colleges, insufficient ideological and political education ability of counselors requires that the team of counselors strengthen their abilities. The school needs to take corresponding measures to continuously strengthen the professional ability of training counselors, thereby effectively improving the education abilities of the ideological and political education of vocational college counselors.

\section{References}

1. Liu J. The new connotation and new path of the construction of counselors in higher vocational colleges in the new era. School Party Building and Ideological Education 2019; 24: 10-12.

2. Li Y. The role of assistants of higher vocational colleges in the ideological and political education of freshmen. Modern Business and Trade Industry 2019; 4017: 178-179.

3. Xiao L. On the improvement of college counselors' network ideological and political education ability. Talent 2019; 20 : 6-7. 